\title{
2013 Okul öncesi eğitim programının değerler eğitimi bağlamında incelenmesi*
}

\author{
Investigation of 2013 pre-school education program in the context of \\ values in education
}

\begin{abstract}
Makale Geçmişi
Geliş : :11 Ocak 2018

Düzeltme : 06 Şubat 2018

Kabul : 27 Subat 2018

Çevrimiçi : 27 Şubat 2018
\end{abstract}

Makale Türü

Özgün Makale

\section{Article History}

Received : 11 January 2018

Revised :06 February 2018

Accepted : 27 February 2018

Online : 27 February 2018

Article Type

Original Article

\author{
Neriman Aral $^{1}$, Gül Kadan ${ }^{2}$
}

Öz: Çocuğa erken yıllardan itibaren kazandırılan değerler ilerleyen yıllarda toplumsal norm ve kuralların belirlenmesi açısından önemli görülmektedir. Bu düşünceden hareketle, araştırmada 2013 yılında güncellenen ve uygulanmaya başlanan Okul Öncesi Eğitim Programı 2013'de yer alan kazanım ve göstergelerin gelişim alanlarına göre değerler eğitimi açısından incelenmesi amaçlanmıştır. $\mathrm{Bu}$ amaçla araştırmada nitel araştırma yöntemlerinden içerik analizi yöntemi kullanılmıştır. Değerler kuramı doğrultusunda ele alınan değerler kategori ve alt kategorilere ayrılmış ve uzmanların görüşleri doğrultusunda değerler kategorisine son şekli verilmiştir. Belirlenen değerler çocuklara yönelik kazanım ve göstergelerde bulunma durumuna göre analiz edilmiştir. Araştırma sonucunda okul öncesi eğitim programında sorumluluk değerine çok fazla yer verildiği, bunu sırasıyla saygı, dayanışma, güven, sevgi, hoşgörü, özgürlük, eşitlik, dostluk ve adalet değerlerinin izlediği bulunmuştur. Elde edilen sonuçlara bağlı olarak, çocukların bireysel ilgi ve ihtiyaçlarının daha fazla dikkate alınması, tüm değerlerin eşit olarak programla bütünleştirilmesi ve değerler konusunda okul-aile işbirliğinin sağlanması önerilebilir.

Anahtar Kelimeler: Okul öncesi dönem, Okul öncesi eğitim programı, Değerler

\begin{abstract}
It has been aimed to examine the acquisition and indicators in the Pre-school Education Program 2013, updated and implemented in 2013, according to the development areas in terms of values education in the study. For this purpose, content analysis method from qualitative research methods was used. The values addressed with in the direction of the theory of values have been divided into categories and subcategories. The final form of the category of values was given in line with the opinion of experts. The specified values have been analyzed according to their status of acquisition and indicators for children. As a result of the study, it has been found that the value of responsibility was given a great place in the pre-school education program and it is followed by the values of respect, solidarity, trust, love, tolerance, freedom, equality, friendship and justice respectively. Depending on the results obtained, it may be recommended that more attention is paid to the individual interests and needs of children, all values are equally integrated into the program and school-family cooperation is ensured about the values.
\end{abstract}

Keywords: Preschool period, Pre-school education program, Values

\footnotetext{
* 5. Uluslar arası Okul Öncesi Eğitim Kongresinde sözlü bildiri olarak sunulmuştur.

${ }^{1}$ Ankara Üniversitesi Sağlık Bilimleri Fakültesi Çocuk Gelişimi Bölümü, aralneriman@gmail.com

${ }^{2}$ Çankırı Karatekin Üniversitesi Sağlık Bilimleri Fakültesi Çocuk Gelişimi Bölümü, gulkadan@gmail.com
} 


\section{SUMMARY}

\section{Introduction}

The pre-school period, one of the critical periods in which development is fastest, is among the important periods that children have different acquisitions. For this reason, the programs special for this period are vital to support the development of a child. Behaviors acquired during this period form the basis of behaviors in the coming years. It is significant that children gain the values among the living elements that are crucial for the society to live in peace from early years. Protecting the acquired values and passing them on to the future generations is one of the duties to be realized by every individual of the society. The values brought to a child since the early years are regarded important in terms of determining social norms and rules in the forthcoming years. In this context, the characteristics to be acquired by a child from the early years with the programs prepared may be integrated into their daily lives. In this case, it is considered that pre-school education programs are significant. Based on this opinion, it has been aimed to examine the acquisition and indicators in the Pre-school Education Program 2013, updated and implemented in 2013, according to the development areas in terms of values education in the study.

\section{Method}

Content analysis method from qualitative research methods was used. The values addressed within the direction of values, have been divided into categories and subcategories. The final form of the category of values was given in line with the opinion of experts. The categories addressed in the study were the values of responsibility, respect, solidarity, trust, love, tolerance, freedom, equality, justice and friendship. The specified values have been analyzed according to their status of acquisition and being indicators for children.

\section{Results}

As a result of the study, it has been found that the value of responsibility has the highest rate and it is followed by the values of respect, solidarity, trust and love respectively. It has been found that the values of tolerance, freedom, equality, friendship and justice take the least part in the acquisitions and indicators. When examined according to the development areas, it is seen that the value of responsibility is emphasized mostly in cognitive and motor development and self-care skills. In the field of cognitive development, it has been observed that responsibility and solidarity values are the highest. These values are followed by the values of trust, respect, equality, love and justice, respectively. It has been determined that the most emphasized values are solidarity and respect in the field of language development whereas these values are followed by values of responsibility and love, respectively. In the field of social-emotional development, the most emphasized value has been respect and it was followed by the values of love, tolerance, responsibility and freedom, respectively. While responsibility, trust, respect and solidarity values have taken parts at the same rate in psycho-motor development, these 
values are followed by the values of justice, equality and love. In the self-care skills, the value of responsibility has got the highest rate and was followed by the values of trust, solidarity, respect, freedom, tolerance and love, respectively. Generally, when all the acquisitions and indicators were examined, it was determined that the value of responsibility had the highest value; this value was followed by the values of respect, solidarity, trust, love, tolerance, freedom, equality, justice and friendship, respectively.

\section{Conclusion and Discussion}

Emphasizing more on the value of responsibility in the program is regarded important in terms of bringing the value to the children. In the result of the study, it is seen that the second most emphasized value is respect. It is thought that the value of respect is emphasized frequently due to the purpose of bringing the value of respect to a child from the early period and the importance of integrating it with all elements and concepts the child communicates and interacts by considering the development of the child. In the study, it has been determined that the third most emphasized value is solidarity. It is possible to link the existence of the solidarity in the program to the transition of individuality due to the advanced technology. However, individualization may also bring loneliness and social abstraction at the same time. One way to prevent all these negative situations is based on increasing the sense of solidarity. It has been determined that the fourth highest value belongs to the confidence value in the study. Considering the importance of the value of trust for the individual and society, it may be stated that its inclusion in the acquisition and the indicators is essential. After the value of trust, it is seen that the most emphasized value in acquisition and indicators is the value of love. Love is very crucial for a child to develop an autonomous and independent personality. In this case, it enables the growth of a stable individual being mentally healthy. All of these explain why the value of love is given an importance place in the program. According to the research result, the fact that the least emphasized values are the values of tolerance, freedom, equality, friendship and justice is thought-provoking.

In the direction of the results obtained, the following can be suggested:

- Quite important universal values are the fact that children are absorbed into their educational programs, which they are exposed to much in their daily lives,

- Distributing these values equally to all development areas,

- Revisiting non-highlighted values in development areas,

- It may be advisable to undertake studies to determine where teachers are applying these values. 


\section{GİRIŞ}

Okul öncesi dönem, çocuğun ve dolayısıyla bireyin hayatını şekillendiren en kritik dönemlerden birisi olması açısından önemli bir yere sahiptir. Çocuk bu dönemde tüm gelişim alanlarında hızlı ilerlemeler yaşamasının yanında, bilgiyi rahatlıkla alabileceği bir dönemde de bulunmaktadır (Sapsağlam ve Ömeroğlu, 2016; Symons ve Clark, 2000). Bu dönemde öğrenme merakı üst düzeye çıkmaktadır. Bu dönemin özelliklerinden yararlanılarak çocuklara birçok davranışla birlikte değerlerde kazandırılabilir (Dereli- İman, 2014; Yaka ve ark., 2014). Değerler eğitiminin temelleri de bu dönemde atılmaktadır (Balat ve Dağal, 2009). Ancak bu dönem çocuklarının değerler eğitimine yönelik bilgileri alabilmesi için kullanılan yöntemler de oldukça önemlidir. Bilindiği gibi okul öncesi dönem, Piaget'nin gelişim aşamalarında işlem öncesi döneme karşılık gelmekte, bu dönemde çocuklar soyut kavramları anlamakta zorlanmaktadır. $\mathrm{Bu}$ nedenle çocuklara kazandırılacak beceriler ve değerlere yönelik davranışların somutlaştırılarak verilmesi önem kazanmaktadır (Aral, 2011). Değer, bir toplumda arzulanan, değerli görülen ve olması istenen kurallar ve ilkeler olarak tanımlanabilir (Sagiv, 2002; Cooper, 2014). İnsanların davranışlarını yönlendiren, onları motive eden değerler, aynı zamanda kişilerin bir işi yaparken de karar verme süreçlerini birebir etkileme özelliğine sahiptir (Sagiv, 2002; Schafer, 2012; Schwartz, 1994). Bununla birlikte değerler yaşayan birer unsur olduğu için bulunduğu toplumdan etkilenmekte (Davidov, 2010) ve toplumu da etkilemektedir (Döring, 2010). Bu kapsamda çocukların değerleri edinmesinde aile ve okula büyük görevler düşmektedir. Aile ve okul, çocukların ahlak gelişimini etkilemekte ve okul çocukları değerler eğitimiyle donanmış bir birey olarak topluma hazırlamaktadır (Brownlee ve ark., 2016). Çocukların erken yıllardan itibaren okul öncesi eğitim kurumuna başladıkları göz önüne alındığında, diğer alanlarda olduğu gibi değerlerinde kazandırılmasında aileden sonra etkin kurumun okul olduğu vurgulanmaktadır. Bu bağlamda okullarda uygulanan programlar değerler açısından önem kazanmaktadır. Değerlerin günlük yaşantının bir parçası haline getirilerek çocuğa kazandırabilmek için ona yönelik düzenleme ve uygulamaların yapılması gerekmektedir. Çocuklara değerlerin kazandırılmasına yönelik yapılan araştırmalarda, değerlerin eğitim programları ile bütünleştirilerek verildiği görülmektedir (Akpınar ve Özdaş, 2013; Brownlee ve ark., 2016; Johansson, 2011; Meydan ve Bahçe, 2010; Sapsağlam ve Ömeroğlu, 2016; Siguardordottir ve Einarsdottir, 2016; Şirin ve ark., 2016; Thornberg, 2016; Ulavere ve Veisson, 2015; Utyupova ve ark., 2016).

Kaya ve arkadaşları (2015) yaptıkları araştırmada drama eğitimi ile çocuklara değerlerin verilebileceği sonucuna ulaşmışlardır. Yapılan başka çalışmalarda da okuldaki değerler 
eğitiminin yanı sıra, aile katılımı değerler eğitimi programlarıyla da çocuklara değerlerin kazandırılabileceği ortaya konmuştur (Crowther, 1995; Dereli-İman, 2014). Yapılan çalışmalarda da görüldüğü gibi çocukların değerleri kazanmasında gelişimsel özellikleri ile birlikte, yaşantılar, çocuğun iletişim ve etkileşimde bulunduğu ortam ve bu ortamda yer alan her türlü öğe ve bunlar doğrultusunda hazırlanan program önemli bir yer tutmaktadır (Sapsağlam ve Ömeroğlu, 2016). Okul öncesi dönem çocuklarına verilen eğitimin hem kazanım ve göstergelerle desteklenmesi ve hem de bu öğelerin içine sindirilmesi nedeniyle, değerlerin de bu eğitimin bir parçası olarak yer alması büyük önem taşımaktadır (MEB, 2013). Çocukların yaparak-yaşayarak öğrendikleri ve okul öncesi dönemin önemi göz önüne alındığında, kazanım ve göstergelerin önemi daha da iyi anlaşılabilmektedir. Çocukların hem geleceğine yapılan bir yatırım olarak görülen, hem de sosyal gelişim alanlarında önemli yer tutan değerlerin kazanım ve göstergelerde bulunması gerekmektedir. Kazanım ve göstergelerde yer alan değerlerin hangi oranda yer aldığının belirlenmesi, eksik olan kısımların tamamlanabilmesi açısından hayatidir. Bu düşünceden hareketle araştırmada Okul Öncesi Eğitim Programı 2013'de yer alan kazanım ve göstergelerin gelişim alanlarına göre değerler açısından incelenmesi amaçlanmıştır.

\section{YÖNTEM}

Okul Öncesi Eğitim Programı 2013'de yer alan kazanım ve göstergelerin gelişim alanlarına göre değerler açısından incelenmesi amacıyla gerçekleştirilen çalışmada nitel araştırma yöntemlerinden içerik analiz yöntemi kullanılmıştır. "İçerik analizi, bir metnin bazı sözcüklerinin belirli kurallara dayalı kodlamalarla daha küçük kategoriler ile özetlendiği, sistematik ve yenilenebilir bir teknik olarak tanımlanmaktadır. İçerik analizi metin veya metinlerden oluşan bir küme içindeki belli kelimelerin veya kavramların varlığını belirlemek amacıyla kullanılmaktadır. Araştırmacılar bu kelime ve kavramların varlığını, anlamları ve ilişkilerini belirler ve analiz ederek metinlerdeki mesajlara ilişkin çıkarımlarda bulunurlar” (Büyüköztürk ve ark., 2016). İçerik analizi, araştırmada belirlenen amaç doğrultusunda kazanım ve göstergelerde yer verilen değerlerin hangi oranda yer aldığını saptamak amacıyla yapılmıştır. Bunun için okul öncesi eğitimde çocuklara öğretilmesi gereken değerler ilgili literatür kapsamında, Türk toplumunun ve tüm toplumlarda yer alan evrensel değerlerin özelliklerine göre belirlenmiştir. Bu belirleme işleminden sonra kazanım ve göstergelerin hepsi tek tek, bu değerlerin bulunma durumuna göre analiz edilmiştir. İlgili literatür incelendiğinde ve Türk toplumunun kültürel özelliklerine göre okul öncesi dönemde kazandırılması gereken değerlerin sırasıyla, sorumluluk, paylaşma, dürüstlük, saygı, sevgi, işbirliği olduğu belirlenmiştir (Yalçın ve ark., 2012). Ancak değerlerin gelecek nesillere aktarılmasında aynı 
zamanda tüm toplumlarda yer alan evrensel değerlerin de çocuklara kazandırılması büyük önem taşımaktadır. Çünkü bilindiği gibi çocuklar çok erken yaşlardan itibaren kitle iletişim araçlarıyla karşılaşmakta ve bu kitle iletişim araçları vasıtasıyla da dünyanın pek çok yerindeki kültürel değerlerden etkilenebilmektedirler. $\mathrm{Bu}$ durum göz önüne alındığında, çocuklara gelişim özelliklerine göre evrensel değerlerin verilmesi önem arz etmektedir. Çocukların gelişim dönemlerine göre okul öncesi dönemde verilmesi gereken bu değerler ise, güven, hoşgörü, özgürlük, eşitlik, adalet ve dostluktur (Ulavere ve Veisson, 2015). Gelişim alanlarına göre değerlerin incelenmesinin nedeni, okul öncesi eğitim programlarının çocukların tüm gelişim alanlarını göz önüne alarak hazırlanmasıdır. Dolayısıyla tüm gelişim alanlarında değerlere ne oranda yer verildiğinin belirlenmesi, çocuklara erken yaşlardan itibaren verilmesi planlanan değerlerin kalıcılığı açısından önem taşımaktadır. Çünkü bu şekilde eksikler görülerek zamanında müdahale şansı olabilecektir.

Araştırmada Okul Öncesi Eğitim Programı 2013'deki değerleri belirleyebilmek için içerik analiz formu kullanılmıştır. Formda yer alan kategori ve alt kategoriler literatür kapsamına dayalı olarak oluşturulmuştur. Oluşturulan form üç uzmanın görüşüne sunulmuştur. Alan uzmanlarından birisi Çocuk gelişimi alanında Profesör, biri yardımcı doçent ve diğeri ise Ölçme ve değerlendirme alanında Profesördür. Alan uzmanları Türkiye'de farklı üniversitelerde görev yapmaktadırlar. Alan uzmanlarından alınan öneriler doğrultusunda form düzenlenerek uygulamaya hazır hale getirilmiştir.

Tablo 1. İçerik analiz formu

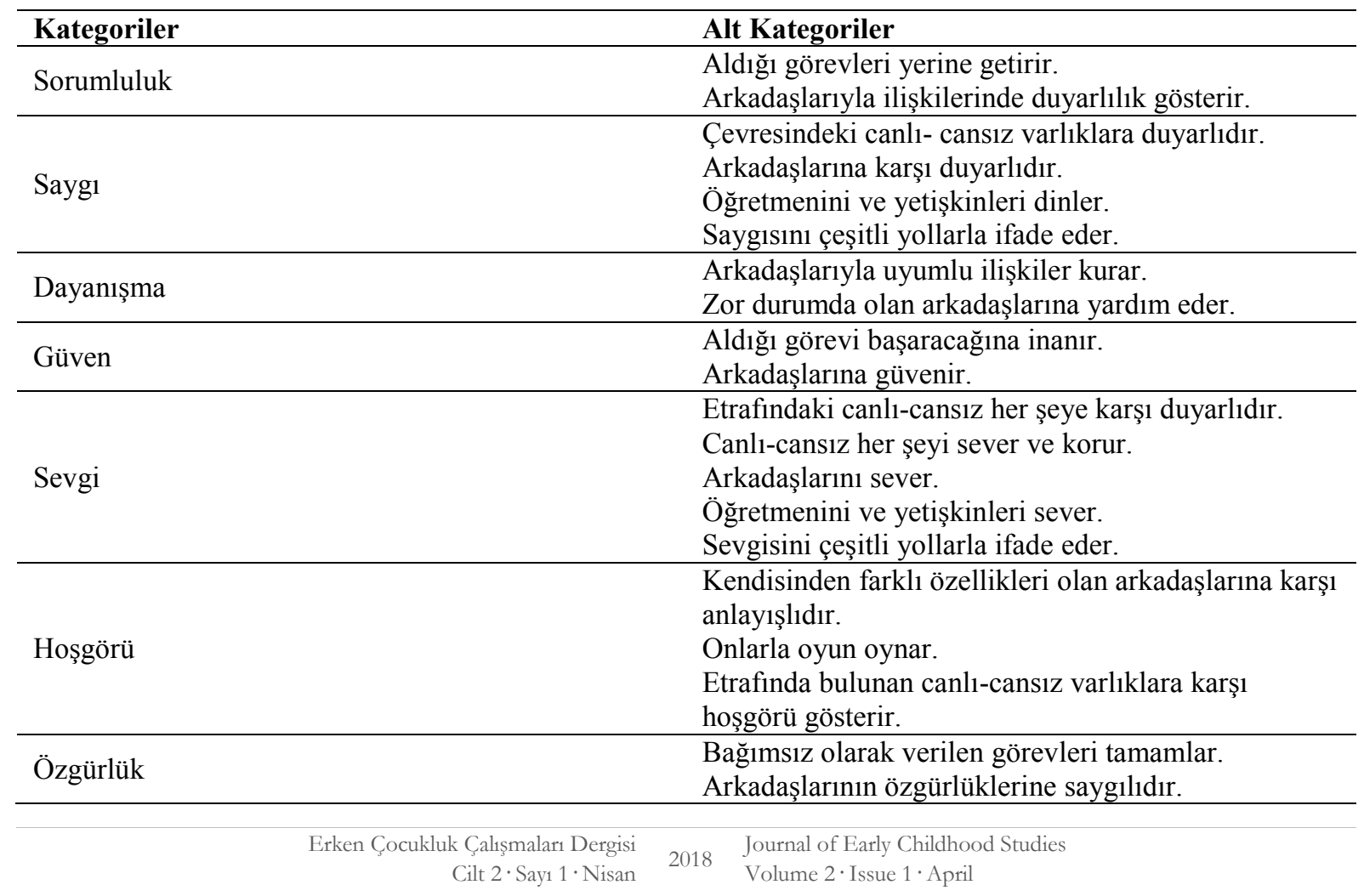




\begin{tabular}{ll}
\hline & Dayatmalardan uzaktır. \\
\hline \multirow{2}{*}{ Esitlik } & Kendisinden farklı özellikte olan akranlarıyla da \\
& dostluklar kurar. \\
\hline \multirow{3}{*}{ Adalet } & Yaptı̆̆ işlerde ve alacağı sorumluluklarda adil \\
& davranır. \\
\hline \multirow{2}{*}{ Dostluk } & Akranlarına karşı adaletli davranır. \\
& Akranlarılyla olumlu ilişkiler kurar. \\
& Farklılıklara saygı gösterir. \\
\hline
\end{tabular}

İçerik Analiz Formu doğrultusunda Okul Öncesi Eğitim Programı 2013'de yer alan kazanım ve göstergeler değerler açısından değerlendirilmiştir. Tüm kazanım ve göstergeler her bir gelişim alanı için ayrı ayrı ele alınarak içerik analizi yapılmış, frekans değerleri grafiklerde sunulmuş, değerler ile ilgili olarak kazanım ve göstergeler doğrultusunda çıkarımlarda bulunulmuştur.

\section{BULGULAR}

Her ne kadar okul öncesi eğitim programı etkinlik merkezli bir program olsa da bazı değerlerin bazı gelişim alanlarında daha fazla vurgulanması kaçınılmazdır. Bu gereklilikten hareketle gelişim alanlarında bu değerlere ne oranda yer verildiğinin belirlenmesi önem taşımaktadır. $\mathrm{Bu}$ değerlerin gelişim alanlarına göre nasıl verildiğine yönelik yapılan analizlere aşağıda yer verilmiştir.

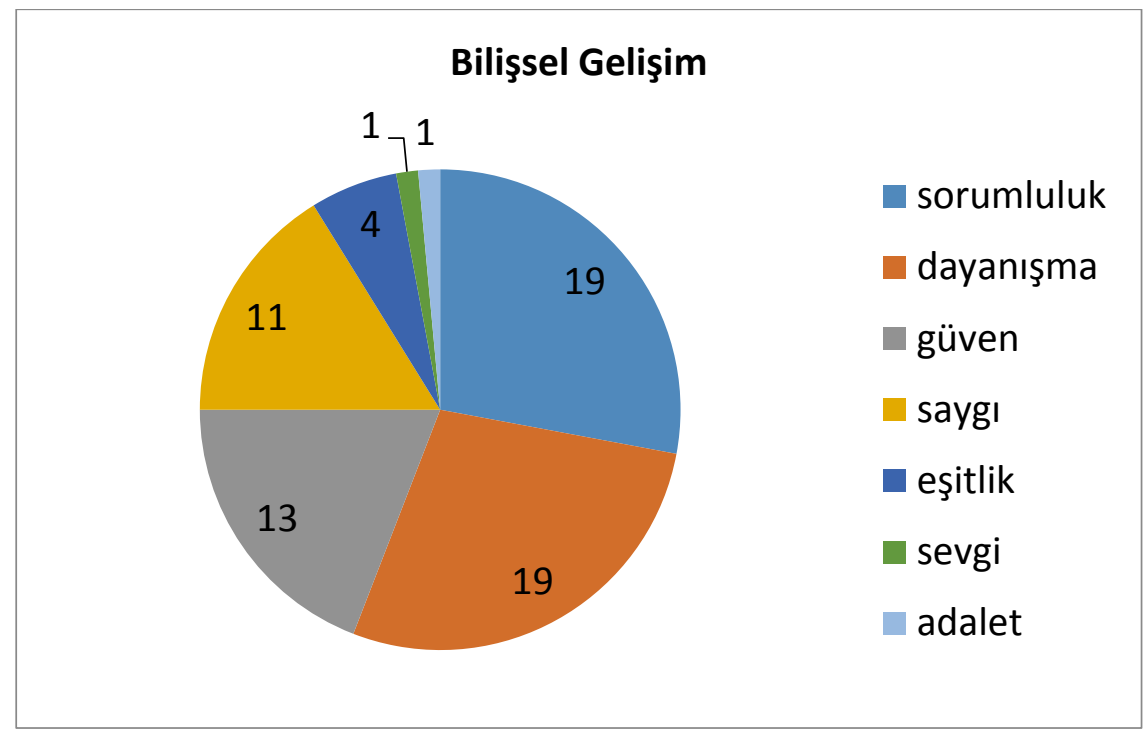

Şekil 1. Bilişssel gelişime yönelik kazanim ve göstergelerde değerler

Okul Öncesi Eğitim Programı 2013'de bilişsel gelişim alanı ile ilgili 21 kazanım bulunmaktadır. Bu kazanımlarda değerler kategorisinde yer alan değerlerden sorumluluk, dayanışma, güven, saygı, eşitlik, sevgi, adalet değerlerine yer verildiği, bu değerlerin 68 kez vurgulandığı, Şekil 1'de de görüldüğü gibi tüm kazanım ve göstergelerde sorumluluk (n=19), dayanışma ( $n=19)$ değerleri ile ilgili ifadelerin en fazla vurgulandığı belirlenmiştir Sorumluluk 
ve dayanışma değerini ise sırasıyla güven $(n=13)[K-1, K-2, K-3, K-4, K-5, K-8, K-10, K-12$, K-14, K-17, K-18, K-19, K-21]; sayg1 (n=11) [K-1, K-2, K-4, K-5, K-9, K-10, K-15, K-16, K17, K-18, K-19]; eşitlik (n=4) [K-9, K-10, K-12, K-13]; sevgi $(n=1)$ [K-1]; adalet (n=1) [K-13] değerlerinin izlediği belirlenmiştir. Eşitlik, adalet ve sevgi değerlerinin bilişsel gelişim ile ilgili kazanım ve göstergelerde çok az yer aldığı bulunmuştur.

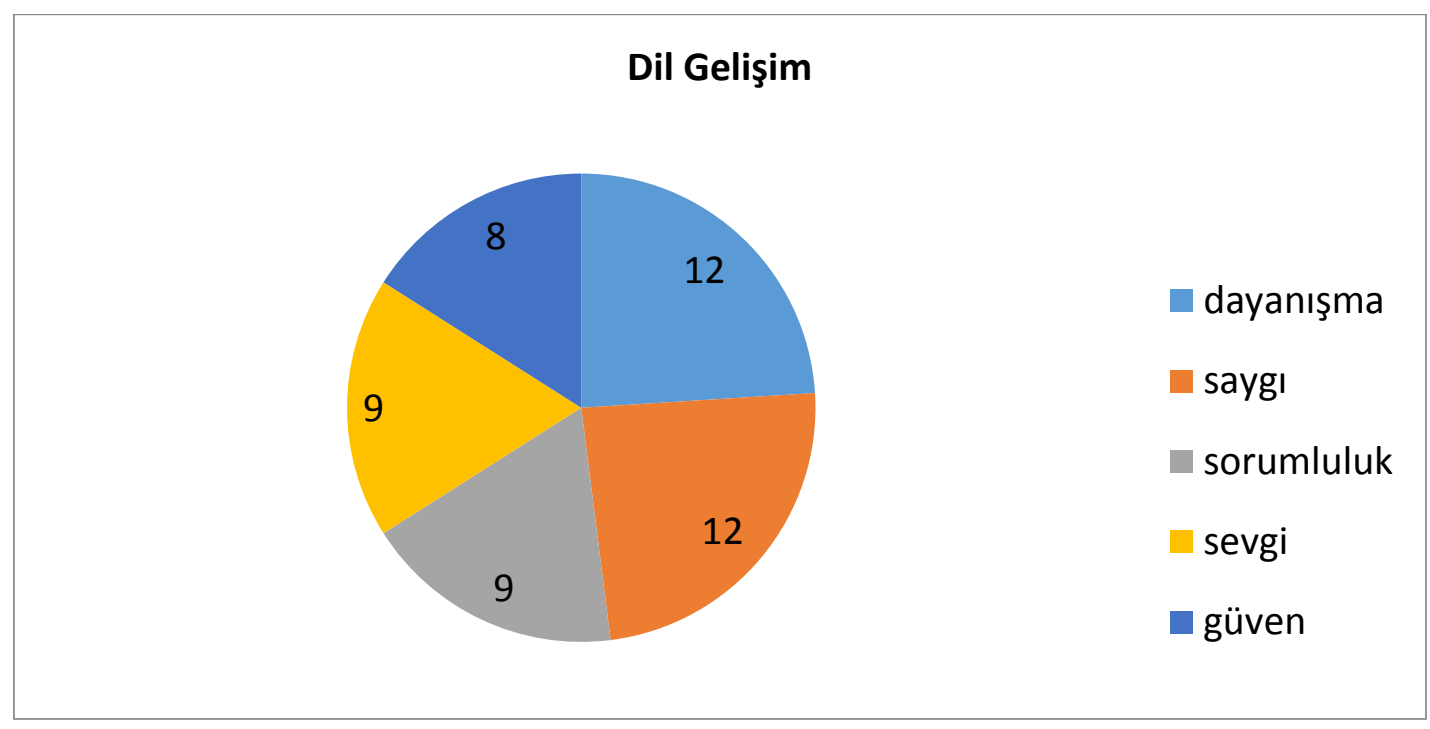

Şekil 2. Dil gelişimine yönelik kazanım ve göstergelerde değerler

Okul Öncesi Eğitim Programı 2013'de dil gelişim alanı ile ilgili 12 kazanım bulunmaktadır. Dil gelişimi ile ilgili kazanımlarda değerler kategorisinde yer alan dayanışma, saygı, sorumluluk, sevgi ve güven değerlerine yer verildiği, bu değerlerin kazanım ve göstergelerde 48 kez ifade edildiği, Şekil 2'de de görüldügü gibi dayanışma $(n=12)$ ve saygı $(n=12)$ değerlerine daha fazla yer verildiği görülmektedir. Dayanışma ve saygı değerlerine tüm kazanım ve göstergelerde yer verilirken, bu değerleri sırasıyla sorumluluk (n=9) [K-2, K-3, K-4, K-5, K- 8, K- 9, K- 10, K-11, K-12]; sevgi (n=9) [K-3, K- 4, K-5, K6, K- 7, K- 8, K-9, K- 11, K- 12]; güven $(n=8)$ [K-3, K-4, K- 5, K- 6, K-8, K-10, K-11, K- 12] değerlerinin izlediği belirlenmiştir.

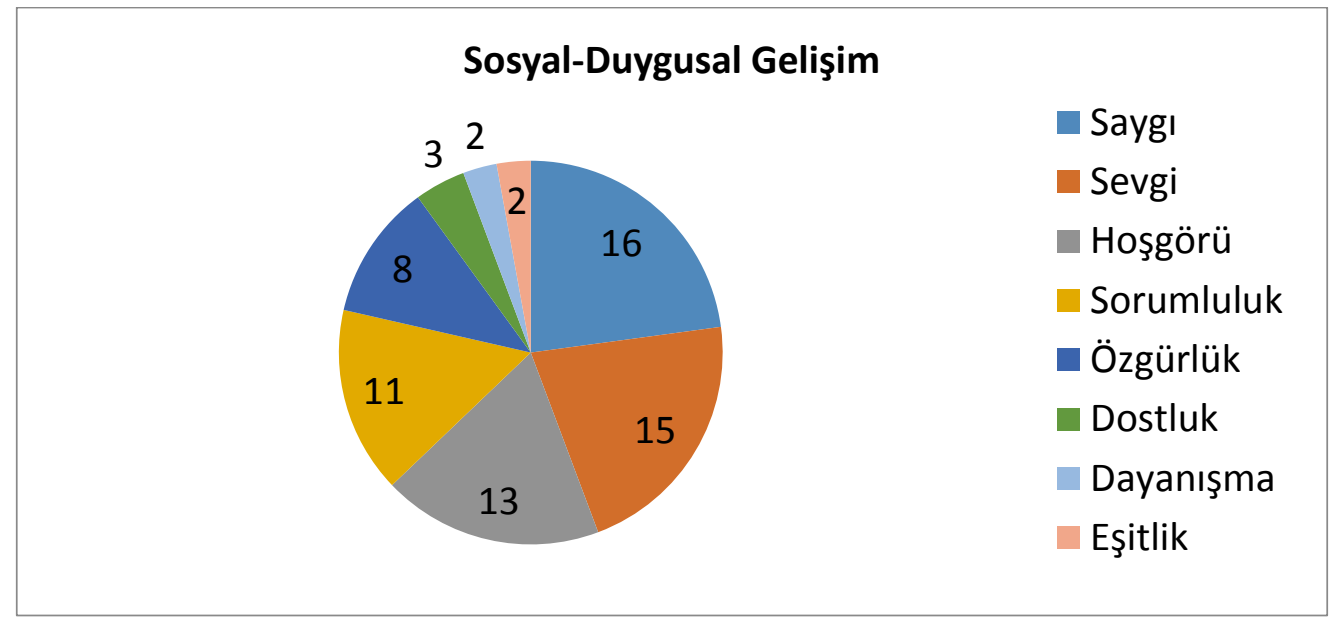


Şekil 3. Sosyal-duygusal gelişime yönelik kazanım ve göstergelerde değerler

Okul Öncesi Eğitim Programı 2013'de sosyal-duygusal gelişim alanı ile ilgili 17 kazanım bulunmaktadır. Sosyal-duygusal gelişim alanı ile ilgili kazanımlarda değerler kategorisinde yer alan saygı, sevgi, hoşgörü, sorumluluk, özgürlük, dostluk, dayanışma, eşitlik değerlerine yer verildiği, bu değerlerin kazanım ve göstergelerde 70 kez ifade edildiği, Şekil 3'de de görüldüğü gibi saygı değerine en fazla yer verildiği görülmektedir. Kazanım 17 dışında tüm kazanımlarda yer alan saygı değerini, sevgi $(n=15)$ değerinin izlediği ve Kazanım 2 ve Kazanım 4 dışında tüm kazanımlarda olduğu bulunmuştur. Sevgi değerini ise sırasıyla hoşgörü $(n=13)[K-1, K-2$, K- 3, K- 4, K- 5, K- 6, K-8, K- 9, K-10, K- 12, K- 13, K-15, K-16]; sorumluluk (n=11) [K-2, K- 3, K-6, K-7, K- 10, K- 12, K-13, K-14, K- 15, K-16, K-17]; özgürlük (n=8) [K-3, K- 6, K7, K-11, K- 12, K- 13, K-14, K- 15]; dostluk (n=3) [K-4, K-8, K- 9]; dayanışma (n=2) [K-2, K5]; eşitlik (n=2) [K-3, K-6] değerlerinin izlediği belirlenmiştir. Dostluk, dayanışma ve eşitlik değerlerine sosyal-duygusal gelişim ile ilgili kazanımlarda çok az yer verildiği bulunmuştur.

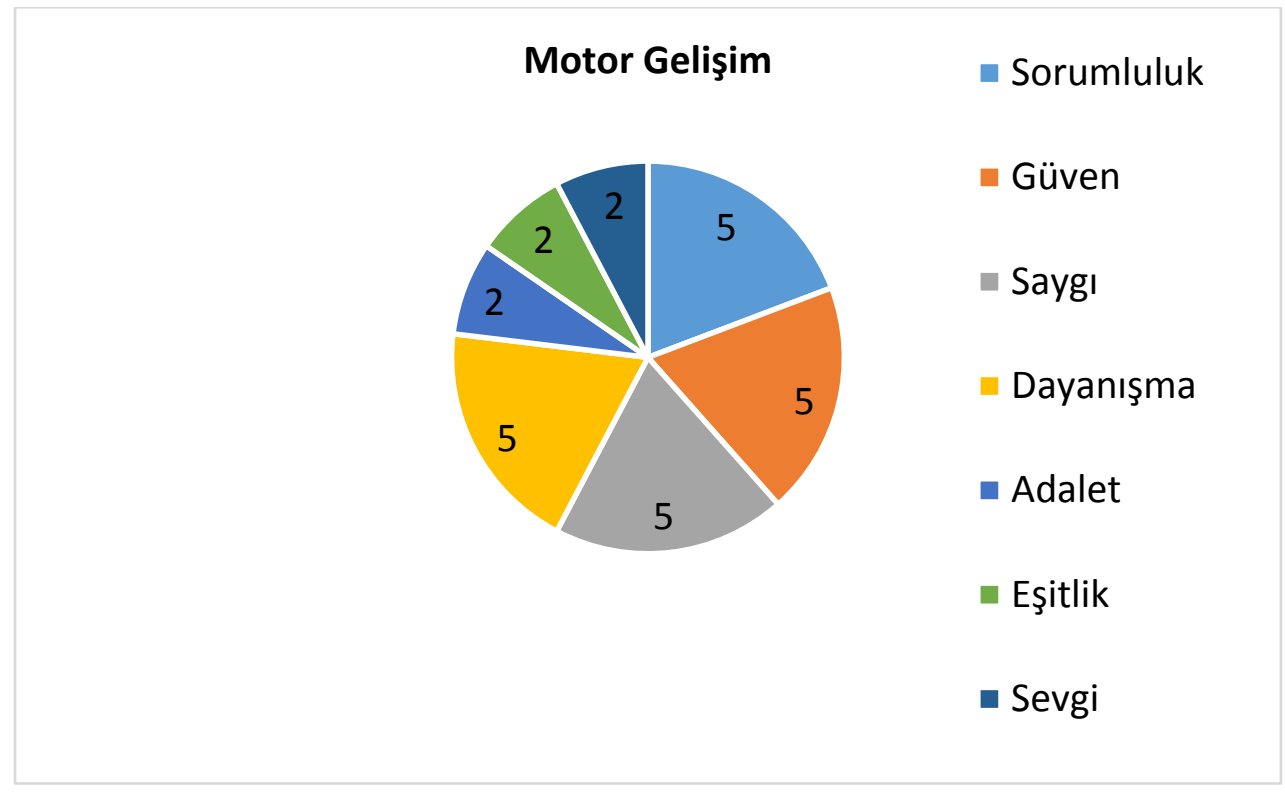

Şekil 4. Motor gelişime yönelik kazanım ve göstergelerde değerler

Okul Öncesi Eğitim Programı 2013'de motor gelişim alanı ile ilgili 5 kazanım bulunmaktadır. Motor gelişim ile ilgili kazanımlarda değerler kategorisinde yer alan sorumluluk, güven, sayg1, dayanışma, adalet, eşitlik, sevgi değerlerine yer verildiği, bu değerlerin kazanım ve göstergelerde 26 kez ifade edildiği, Şekil 4'de de görüldüğ̈̈ gibi sorumluluk (n=5); güven $(n=5)$; saygı $(n=5)$; dayanışma $(n=5)$ değerleri ile ilgili ifadelerin en fazla vurgulandı̆̆ belirlenmiştir. Sorumluluk, güven, saygı ve dayanışma değerleri tüm kazanımlarda yer alırken, bu değerleri sırasıyla adalet $(n=2)[K-1, K-2]$; eşitlik $(n=2)[K-1, K-2]$; sevgi $(n=2)[K-2, K-$ 4] değerlerinin izlediği belirlenmiştir. 


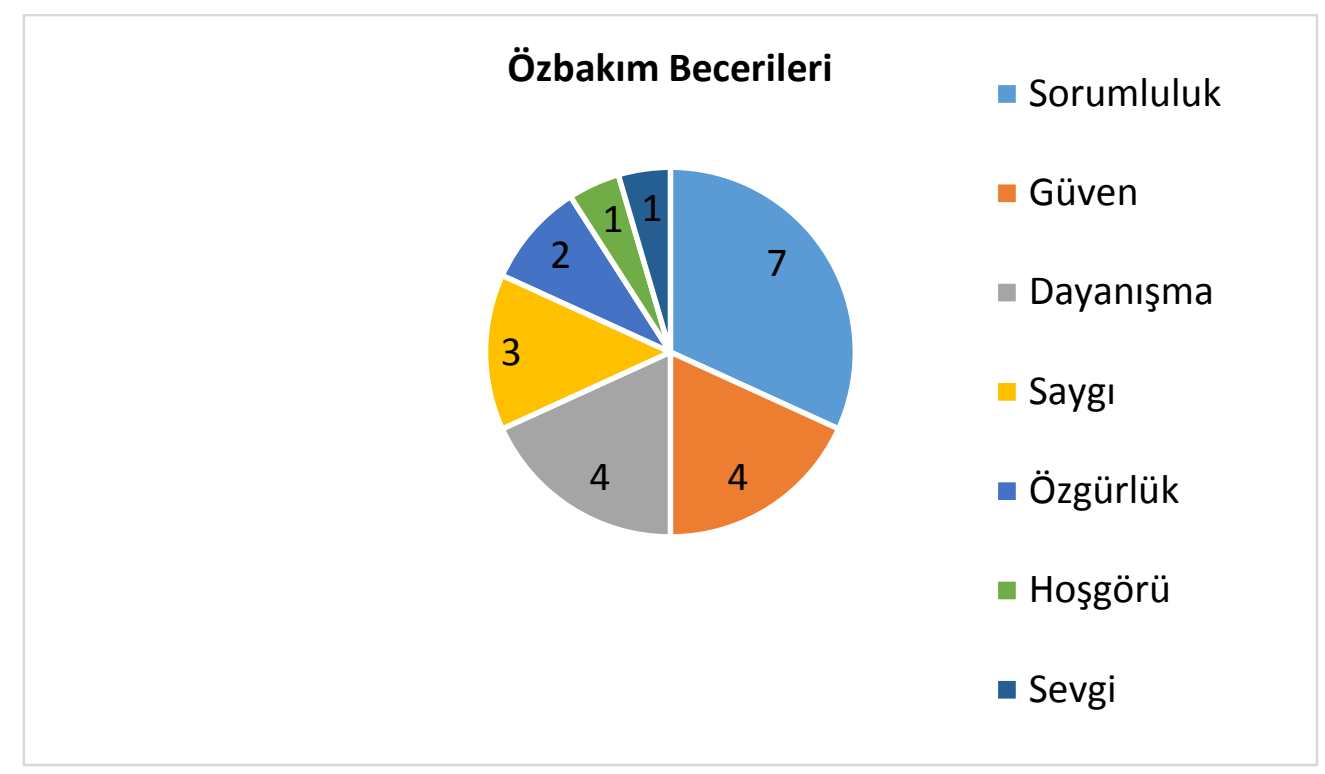

Şekil 5. Özbakım becerilerine yönelik kazanım ve göstergelerde değerler

Okul Öncesi Eğitim Programı 2013'de özbakım becerilerine ait 8 kazanım bulunmaktadır. Bu kazanımlarda değerler kategorisinde yer alan değerlerin sorumluluk, güven, dayanışma, saygı, özgürlük, hoşgörü, sevgi değerleri olduğu, bu değerlerin 22 kez vurgulandığı ve Kazanım 5 dışındaki tüm kazanım ve göstergelerde sorumluluk $(n=7)$ değeri ile ilgili ifadelerin en fazla vurgulandığı belirlenmiştir (Şekil 5). Sorumluluk değerini ise sırasıyla güven $(n=4)[K-1, K-3$, K- 4, K- 6]; dayanışma (n=4) [K-2, K- 3, K- 6, K- 7]; saygı (n=3) [K-4, K- 5, K-8]; özgürlük $(n=2)[K-5, K-8]$; hoşgörü $(n=1)$ [K- 5]; sevgi $(n=1)$ [K- 5] değerlerinin izlediği belirlenmiştir. Özgürlük, hoşgörü ve sevgi değerlerine özbakım becerileri ile ilgili kazanım ve göstergelerde çok az yer verildiği bulunmuştur.

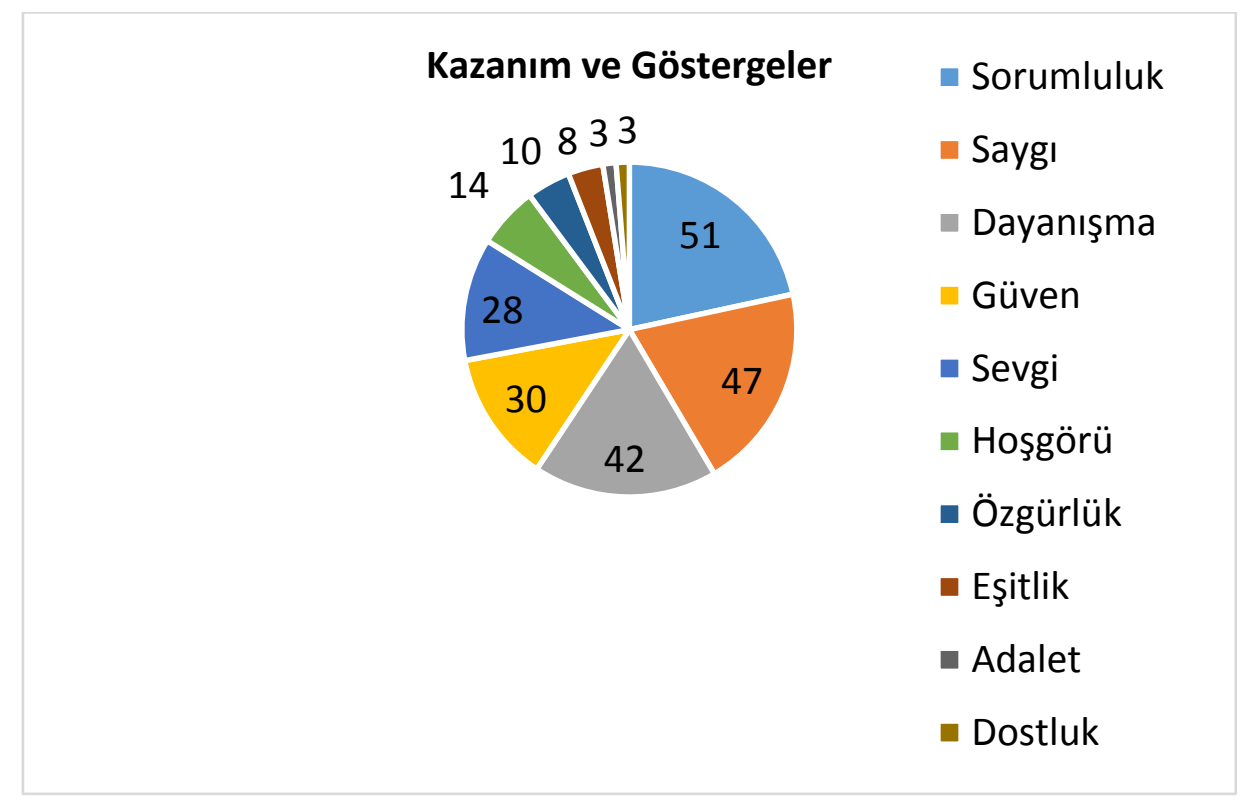

Şekil 6. Kazanım ve göstergelerde yer alan değerler ve gelişim alanları 
Okul Öncesi Eğitim Programı'nda yer alan kazanım ve göstergeler değerler açısından genel olarak değerlendirildiğinde kazanım ve göstergelerde sorumluluk $(\mathrm{n}=51)$ [bilişsel alanda 19, dil alanında 9, sosyal-duygusal alanda 11, motor gelişim alanında 5, özbakım becerilerinde 7]; sayg1 $(\mathrm{n}=47)$ [bilişsel alanda 11, dil alanında 12, sosyal-duygusal alanda 16, motor gelişim alanında 5, özbakım becerilerinde 3]; dayanışma $(\mathrm{n}=42)$ [bilişsel alanda 19, dil alanında 12, motor gelişim alanında 5, sosyal-duygusal alanda 2, özbakım becerilerinde 4] değerlerinin en fazla vurgulandığı, güven $(\mathrm{n}=30)$ [bilişsel alanda 13 , dil alanında 8 , motor gelişim alanında 5 , özbakım becerilerinde 4]; sevgi $(\mathrm{n}=28)$ [bilişsel alanda 1, dil alanında 9, sosyal-duygusal alanda 15, motor gelişim alanında 2, özbakım becerilerinde 1] değerlerindeki oranların birbirine yakın olduğu belirlenmiştir. Hoşgörü $(\mathrm{n}=14)$ [sosyal-duygusal alanda 13, özbakım becerilerinde 1]; özgürlük $(n=10)$ [sosyal-duygusal alanda 8 , özbakım becerilerinde 2]; eşitlik $(n=8)$ [bilişsel alanda 4, sosyal-duygusal alanda 2, motor gelişim alanında 2]; adalet $(\mathrm{n}=3)$ [bilişsel alanda 1 , motor gelişim alanında 2]; dostluk ( $\mathrm{n}=3$ ) [sosyal-duygusal alanda 3] değerlerinin ise en az vurgulandığı görülmektedir (Şekil 6).

\section{SONUÇ ve TARTIŞMA}

Okul Öncesi Eğitim Programı 2013'de yer alan kazanım ve göstergelerin gelişim alanlarına göre değerler açısından incelemesi amacıyla yapılan araştırmada, en yüksek oranı sorumluluk değerinin aldığı, bunu sırasıyla saygı, dayanışma, güven, sevgi değerlerinin izlediği; hoşgörü, özgürlük, eşitlik, dostluk ve adalet değerlerinin ise kazanım ve göstergelerde en az yer aldığ1 bulunmuştur. Gelişim alanlarına göre bakıldığında sorumluluk değerine en fazla bilişsel ve motor gelişim ile özbakım becerilerinde vurgu yapıldığı görülmektedir. Sorumluluk değeri, çocuğun hayatta aktif olarak rol almasını sağlarken, aynı zamanda öğrenme etkinliklerini başarıyla yerine getirmesine de katkı sağlamaktadır (Sezer ve ark., 2017). Erken çocukluk döneminde sorumluluk duygusunun gelişmesi ve desteklenmesi ileriki dönemler için temel oluşturmaktadır. Hayatın en kritik dönemlerinden biri olan okul öncesi dönemde çocuklara verilecek eğitimlerle aynı zamanda ileriye yatırım yapılmaktadır (Dereli- İman, 2014). Programda sorumluluk değerine daha fazla vurgu yapılması, çocuklara bu değerin kazandırılması açısından önemli görülmektedir. Nitekim yapılan araştırmalarda da, çocuklar için hazırlanan eğitim programlarında (Ulavere ve Veisson, 2015; Utyupova vd., 2016), romanlarda (Körükçü ve ark., 2016; Özbay ve Taysi- Karakuş, 2011) ve çizgi filmlerde (Sevim, 2013) sorumluluk değerine ilişkin vurgunun daha fazla olduğu görülmektedir. Sorumluluk değerinin yüksek oranda vurgulanması, globalleşen dünya ile bağlantılandırılabilir. Nitekim globalleşen dünyada bireylerin kendilerinden beklenen görevleri yerine getirebilmeleri 
sorumluluk değerlerine sahip çıkmalarıyla mümkün hale gelebilecektir (Johansson, 2009). Tüm bu bilgiler göz önüne alındığında gerek eğitim programlarında, gerek romanlarda ve gerekse çizgi filmlerde sorumluluk değerinin daha yüksek çıktığı düşünülmektedir.

Araştırma sonucunda en fazla vurgulanan ikinci değerin saygı değerine ait olduğu görülmektedir. Saygı değerine tüm gelişim alanlarındaki kazanımlarda yer verildiği görülmektedir. Saygı, insan ilişkilerinin temelini oluşturan, bir toplumun huzurlu inşasında oldukça etkili olan bir değerdir. Saygının erken dönemden itibaren çocuklara kazandırılmasını (Yazıcı ve Yazıcı, 2015) ve çocuğun gelişiminin göz önüne alınarak iletişim ve etkileşimde bulunduğu tüm öğe ve kavramlarla bütünleştirilmesinin önemli olduğu vurgulanmaktadır (Aral, 2011). Körükçü ve arkadaşlarının (2016), okul öncesi dönem çocuk kitaplarında yer alan değerleri inceledikleri çalışmalarında en fazla saygı değerine vurgu yapıldığını, Mocan (2011) çocuk romanlarında saygı değerinin sıklıkla vurgulandığını, Özbay ve Taysi-Karakuş (2011) çocuk hikayelerinde en fazla vurgulanan değerin saygı olduğunu belirtmişlerdir. Sevim (2013) çizgi filmleri incelediği çalışmasında, saygı değerinin en fazla vurgulandığını belirtirken, Siguardottir ve Einarsdottir (2016) ve Thornbeg (2016) okul öncesi eğitim programlarını inceledikleri çalışmalarında, en fazla saygı değerinin vurgulandığı sonucuna ulaşmışlardır. Tüm bu sonuçlar da saygı değerinin çizgi film, hikaye kitabı, roman ve eğitim programlarında oldukça fazla vurgulanan bir değer olduğunu göstermekte ve araştırma sonucunu desteklemektedir.

Araştırmada en çok vurgulanan üçüncü değerin dayanışma olduğu belirlenmiştir. Bu değere tüm gelişim alanlarındaki kazanım ve göstergelerde yer verilmiştir. Dayanışmanın programda yer almasını ilerleyen teknolojiyle bireyselliğe geçişe bağlamak mümkün görülmektedir. Ancak bireyselleşme aynı zamanda yalnızlık ve sosyal soyutlanmayı da beraberinde getirebilir. $\mathrm{Bu}$ durum ise uzun vadede toplumda istenmeyen sosyolojik olayların ortaya çıkmasına neden olabilir. Tüm bu olumsuz durumları önlemenin bir yolu ise dayanışma duygusunu arttırmakta yatmaktadır (Şimşek 2012; Temizyürek ve Karagöl, 2016). Dayanışma sadece istenmeyen sosyolojik olayların ortaya çıkmasını önlemekle kalmamakta, aynı zamanda çocuğun gelişim alanlarına katkı yaparak, onun sağlıklı bir birey olmasına da katkıda bulunmaktadır (Johansson, 2009). Bireylerin huzurlu ve mutlu olmalarında dayanışmanın önemini bilen toplumlar dayanışma değerini çocuklara yönelik uyguladıkları tüm programların içine sindirmişlerdir (Blum, 2012). Tüm bu ifade edilenlere dayanarak araştırma sonucunda dayanışma değerinin en fazla vurgulanan değerlerden biri olduğu söylenebilir. 
Araştırmada en yüksek dördüncü değerin güven değerine ait olduğu ve bu değerin sosyalduygusal gelişim alanı dışındaki tüm gelişim alanlarında vurgulandığı bulunmuştur. Güven, insan ilişkilerinin temelini oluşturan bir değerdir. Temeli çok erken dönemde atılan ve erken çocukluk döneminde de desteklenen güven değeri ile çocuk ruhsal anlamda doyumu sağlamakta ve bu da işlevsel bir toplumun oluşmasına katkı sağlamaktadır (Güneş, 2016). Güven değerinin birey ve toplum için önemi göz önüne alındığında kazanım ve göstergelerde yer almasının önemli olduğu söylenebilir.

Güven değerinden sonra kazanım ve göstergelerde en fazla vurgulanan değerin sevgi değeri olduğu görülmektedir. Sevgi değerinin tüm gelişim alanlarında vurgulandığı bulunmuştur. Sevgi çocuk için temel bir ruhsal gıdadır. Çocukta özgüvenin desteklenmesi için oldukça önemlidir. Aynı zamanda sevgi çocuğun özerk ve bağımsız bir kişilik geliştirmesinde oldukça önemlidir. Bu durumda ruh sağlığı yerinde, dengeli bir bireyin yetişmesini sağlamaktadır (Topses, 2006). Tüm bunlarda programda sevgi değerine neden bu kadar yoğun oranda yer verildiğini açıklamaktadır. Nitekim yapılan araştırmalarda da çocuklara yönelik olarak incelenen eğitim programları, dergi, kitap, televizyon programları öğelerinde sevgi değerinin sıklıkla vurgulandığını göstermektedir (Akarsu, 2015; Erol ve Tutak, 2015; Körükçü ve ark., 2016; Kurtdede-Fidan, 2016; Mocan, 2011; Özbay ve Taysi- Karakuş, 2011; Sevim, 2013; Tut ve Kiroğlu, 2017; Yaşaroğlu, 2013).

Araştırmada kazanım ve göstergelerde hoşgörü değerinin daha az vurgulandığı belirlenmiştir. Hoşgörü değerine sosyal-duygusal gelişim alanında yer verildiği görülmektedir. Hoşgörü değerine, bireyin etrafındaki canlı-cansız her türlü varlığı olduğu gibi kabul etmesinin öneminden dolayı (Aslan, 2017) programda yer verilmesinin önemli olduğu düşünülmektedir. Erken çocukluk eğitiminin temel amaçlarından birisi de, çocuğun hem etrafına duyarlılık geliştirmesini sağlamak, hem de risk altındaki çocukları desteklemektir (Kartal, 2007). Doğaldır ki bu amaçların yerine getirilebilmesi de programda hoşgörü değerine yer verilmesiyle mümkün hale gelecektir. Denizel- Güven ve Cevher (2005) okul öncesi öğretmenlerinin, Kurtdede- Fidan (2016) sınıf öğretmenlerinin eğitim faaliyetlerini yönetirken hoşgörü değerine yer verdiklerini, Tut ve Kıroğlu (2017) TRT'de popüler çocuk şarkılarını değerler açısından inceledikleri çalışmalarında hoşgörü değerinin vurgulandığg ve Yaşaroğlu (2013) Hayat Bilgisi ders müfredatını incelediği çalışmasında hoşgörü değerine kazanımlarda yer verildiğini bulması araştırma sonuncunu desteklemektedir. Çocukların çok erken yaşlardan itibaren hoşgörü değerini içselleştirebilmelerinin, onların aynı zamanda daha sosyal olmalarına yardımcı 
olabileceği ve bu durumunda istenen bir toplumun inşasında gerekli olduğu ifade edilmektedir (Kulkofsky ve ark., 2008; Ulavere ve Veisson, 2015)

Araştırmada hoşgörü değerinde olduğu gibi özgürlük değerinin de vurgulandığı ancak bu değerinde programda yeterince yer bulamadığı görülmektedir. Özgürlük değerine sosyalduygusal gelişim alanı ile özbakım becerilerinde yer verildiği belirlenmiştir. Çocuğun faaliyetlerinde kısıtlamalara uğramadan düşünce ve görüşlerini ifade etmesi onun kişilik gelişimine önemli katkılar sağlayacaktır. Özellikle özgürlük değerinin sosyal-duygusal gelişim alanında yüksek oranda çıkmasını, erken dönemde kişilik gelişimininin en iyi temellendirilmesine bağlamak mümkündür. Diğer gelişim alanlarının içinde de yer almasının önemli olduğu düşünülmektedir.

Özgürlük gibi programda eşitlik değerinin de yer aldığı ancak oranının yeterli olmadığı söylenebilir. Eşitlik değeri tüm kazanımlarda sekiz kez tekrar edilmiştir. Bu değerin gelişim alanlarındaki kazanımların sayısına göre değerlendirildiğinde yeterli olmadığı söylenebilir. Dahası eşitlik değeri bilişsel, sosyal-duygusal ve motor gelişim alanlarında vurgulanmış, ancak dil gelişim alanı ile özbakım becerilerinde vurgulanmamıştır. Oysaki eşitlik değeri, eğitim programlarında çocuk hakları açısından ele alınması gereken önemli değerlerden birisidir. Her çocuğun eğitim alma hakkı olması ve her çocuğa aynı mesafede davranılması eşitliğin önemli özelliklerinden biridir (Odegaard, 2013). Eşitlik ilkesine göre, her çocuk bireysel gereksinimleri ve ihtiyaçları ile birbirinden ayrılmakta ve dolayısıyla çocukların öğrenme zaman ve hızları aynı olmamaktadır (Senemoğlu, 2013). Ancak tüm çocukların eğitim haklarının olduğu ve bunun sağlanmasının gerekliliği de yasalarla garanti altına alınmıştır (Serozan, 2000). Bu durumda çocuklara sağlanacak eğitim programlarında eşitlik değerine yer verilmesiyle gerçekleşebilir. Kazanım ve göstergelerde eşitlik değeri istenen ölçüde yer almasa da, programın felsefesi doğrultusunda uygulama sırasında bu değerin ön plana çıktığı söylenebilir.

Araştırmada en az vurgulanan iki değer adalet ve dostluk değeridir. Adalet değerine bilişsel gelişim alanı ile motor gelişim alanında, dostluk değerine ise sosyal-duygusal gelişim alanında yer verildiği belirlenmiştir. Adalet değerine bilişsel ve motor gelişim alanında yer verilmesini çocukların gelişim özellikleri ve bireysel farklılıklarından dolayı bu alanda yaşayabilecekleri zorlanmalar göz önüne alındığında (Aral, 2011; Pedük, 2011) onlara sağlanacak olanaklarında adil olmasını gerektirecektir. Dostluğun ise sosyal-duygusal alanda vurgulanmasını çocukların akran ilişkilerinin bu dönemde sağlıklı olarak kurulma çabalarına bağlamak mümkündür (Trawick- Smith, 2014). Neslitürk ve arkadaşları (2015) nın okul öncesi çocuklarına yönelik hazırladıkları programda dostluk değerine yer vermişlerdir. Dostluk ve adalet kavramlarının 
erken yıllardan itibaren çocuklara kazandırılması gereken değerlerden olmasına rağmen programda çok az yer alması düşündürücüdür.

Okul Öncesi Eğitim Programı 2013'de yer alan kazanım ve göstergelerin gelişim alanlarına göre değerler açısından incelenmesi amacıyla yapılan araştırmada en fazla vurgulanan değerin sorumluluk, saygı, dayanışma, güven ve sevgi değeri olduğu, hoşgörü, özgürlük, eşitlik, dostluk ve adalet değerlerinin ise en az vurgulandığı bulunmuştur.

Elde edilen sonuçlar doğrultusunda;

- Oldukça önemli olan evrensel değerleri, çocukların erken yaşlardan itibaren deneyimlemeleri için onların günlük hayatlarında oldukça fazla maruz kaldıkları eğitim programlarının içine sindirilmesi,

- $\mathrm{Bu}$ değerlerin tüm gelişim alanlarına eşit oranda dağıtılması,

- Gelişim alanlarında vurgulanmayan değerlerin, kazanımlarda tekrar gözden geçirilmesi,

- Öğretmenlerin bu değerleri hangi yönde uyguladıklarını belirlemek için çalışmaların yapılması önerilebilir.

\section{KAYNAKÇA}

Akarsu, S.(2015). Illkokul (1-4) ve ortaokul (5-8) müzik ders kitaplarında yer alan şarkıların değerler bakımından incelenmesi ve dĕgerler ĕgitimine ilişkin ögrenci algıları. Yayınlanmamış Doktora Tezi, Yüzüncü Y1l Üniversitesi Eğitim Bilimleri Enstitüsü, Van.

Akpınar, B. \& Özdaş, F. (2013). "Teachers" values education at primary schools: A qualitative analysis. Firat University Journal of Social Science, 23(2), 105-113.

Aral, N. (2011). Bilişsel gelişim. N. Aral \& G. Baran (eds). In Çocuk gelişimi (ss: 99-156). İstanbul: Ya- Pa Yayınları.

Aslan, S. (2017). İlkokul 4. Sınıf öğrencilerinin hoşgörü eğilimleri ile yardımseverlik tutumlarının çeşitli değişkenler açısından incelenmesi. Inönü Üniversitesi Ĕgitim Fakültesi Dergisi, 18(1), 163-175.

Balat, G.U. \& Dağal, A.B. (2009). Okul öncesi dönemde değgerler ĕgitimi etkinlikleri. Ankara: Kök Yayıncılık.

Blum, L. (2012). Solidarity, equality and diversity as educational values in Western multiethnic socities. E. Johannson \& D. Berthelsen (eds.) In. Spaces for slidarity and individualism in educational contexts. (pg: 33-49). Sweden: Göteburg. 
Brownlee, J.L., Scholes, L., Walker, S. \& Johansson, E. (2016). Critical values education in the early years: Alignment of teachers' personal epistemologies and practices for active citizenship. Teaching and Teacher Education, 56, 261-273.

Büyüköztürk, Ş., Kılıç-Çakmak, E., Akgün, E.Ö., Karadeniz, Ş. \& Demirel, F. (2016). Bilimsel araştırma yöntemleri. Ankara: Pegem Akademi.

Cooper, D. (2014). Character education: A study of an elementary school leadership Academy. Yayınlanmamış Doktora Tezi, Wilmington University, USA.

Crowther, W. (1995). An independent school library-classroom- parent partnership program to encourage respect, responsibility, courtesy and caring for students prekindergarten through eighth grade. Yayınlanmamış Yüksek Lisans Tezi, 05.07.2017 tarihinde http://wwwericed.gov/content.delivery/servlet/ERIC.servlet?accno=ED388964.

erişildi.

Davidov, E. (2010). Testing for comparability of human values a cross countries and time with the third round of the european social survey. International Journal of Comparative Sociology, 51, 171-191.

Denizel- Güven, E. \& Cevher, F.N. (2005). Okul öncesi öğretmenlerinin sınıf yönetimi becerilerinin çeşitli değişkenler açısından incelenmesi. Pamukkale Üniversitesi Eğitim Fakültesi Dergisi, 2(18), 1-22.

Dereli- İman, E. (2014). Değerler eğitimi programının 5-6 yaş çocuklarının sosyal gelişimine etkisi: Sosyal beceri, psikososyal gelişim ve sosyal problem çözme becerisi. Kuram ve Uygulamada Ĕ̌itim Bilimleri, 14(1), 249-268.

Döring, A.K. (2010). Assessing children's values: An explotary study. Journal of Psychoeducational Assessment, 28(6), 564-577.

Erol, K. \& Tutak, M. (2015). Çocuk edebiyatı kapsamında İbrahim Alaettin Gövsa'nın çocuk şiirlerinde değerler eğitimi bağlamında bir bakış. International Journal of Languages' Education and Teaching, 31(1), 210-228.

Güneş, A. (2016). Güvenli bağlanma. İstanbul: Timaş Yayınları.

Johansson, E. (2009). The preschool child of today- The world citixen of tommorow. International Journal of Early Childhood, 41(2), 79-95.

Johansson, E. (2011). Moral discoveries and learning in preschool. N. Pormling \& I. PromlingSamuelsson (eds.) In. Educational encounters: Nordic studies in early childhood didactics. (pp: 127-140). Springer: Science Buisness Media.

Kartal, H. (2007). Erken çocukluk eğitimi programlarından anne-çocuk eğitimi programının altı yaş grubundaki çocukların bilişsel gelişimlerine etkisi. Elementary Education Online, 6(2), 234-248. 
Kaya, Y., Günay, R. \& Aydın, H. (2015). Okul öncesi eğitimde drama yöntemi ile işlenen değerler eğitimi derslerinin farkındalık düzeyindeki etkisi. Sakarya Üniversitesi Journal of Education, 6(1), 23-37.

Körükçü, Ö., Acun-Kapıkıran, N. \& Aral, N. (2016). Schwartz'ın modeline göre 3-6 yaş resimli çocuk kitaplarında değerlerin incelenmesi. Mehmet Akif Ersoy Üniversitesi Ĕgitim Fakültesi Dergisi, 38, 133-151.

Kulkofsky, S., Wang, Q. \& Ceci, S.J. (2008). Do beter stories make beter memories? Narrative quality and memory accuracy in preschool children? Applied Cognitive Psychology, 22, 21-38.

Kurtdede- Fidan, N. (2016). Sınıf öğretmeni adaylarının geleceğe yönelik değerler eğitimi tasarımları. International Journal of Eurasia Social Sciences, 7(22), 161-180.

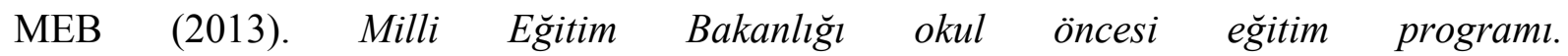
http://docplayer.biz.tr/895440-T-c-milli-egitim-bakanligi-talim-ve-terbiye-kurulubaskanligi-konu-okul-oncesi-egitim-programı.html.

Meydan, A. \& Bahçe, A. (2010). Hayat bilgisi öğretiminde değerlerin kazandırılma düzeylerinin öğretmen görüşlerine göre değerlendirilmesi. Uluslararası Avrupa Sosyal Bilimler Dergisi, 1(1), 20-37.

Mocan, A. (2011). Abdullah Ziya Kozanoğlu'nun tarihi romanlarındaki değerlerin Türkçe eğitimi açısından incelenmesi. Yayınlanmamış Yüksek Lisans Tezi, Muğla Üniversitesi Eğitim Bilimleri Enstitüsü, Muğla.

Neslitürk, S., Özkal, N \& Dal, S. (2015). 5-6 yaş çocuklarının değer kazanım süreçlerine anne değerler eğitimi programının etkisi. Mersin Üniversitesi Ĕ̆itim Fakülteler Dergisi, 11(3), 883-899.

Odegoaard, E. (2013). Early childhood education in Norway and Sweden today: Education for democracy. J. Georgeson \& J. Payler (eds.). In. Early childhood education and care. (pg: 76-80). England: McGrawhill

Özbay, M. \& Taysi- Karakuş, E. (2011). Dede Korkut hikayelerinin Türkçe öğretimi ve değer aktarımı açısından önemi. Pegem Ĕ̈itim ve Öğretim Dergisi, 1(1), 21-31.

Pedük, Ş. (2011). Psikomotor gelişim. N. Aral \& G. Baran (eds). İçinde Çocuk gelişimi. (ss: 71-93). İstanbul: Ya- Pa Yayınları.

Sagiv, L. (2002). Vocational interests and basic values. Journal Career Assess. 10(2), 233-257.

Sapsağlam, Ö. \& Ömeroğlu, E. (2016). Examining the effect of social values education program being applied to nursery school students upon acquiring social skills. Educational Research and Reviews, 11(13), 1262-1271.

Schaefer, M. P. (2012). Determining methods for teaching character education in elementary schools. Yayınlanmamış Doktora Tezi, Northcentral University, Arizona. 
Schwartz, S.H. (1994). Are there universal aspects in the structure and content of human values? Journal Social Issues, 50(4), 19-45.

Senemoğlu, N. (2013). Gelişim-öğrenme ve ögrretim: Kuramdan uygulamaya. Ankara: Yarg1 Kitabevi.

Serozan, R. (2000). Çocuk hukuku. İstanbul: Beta Yayınevi.

Sevim, Z. (2013). Çizgi filmlerin değerler ĕgitimi bakımından karşılaştırılması. Yayınlanmamış Yüksek Lisans Tezi, Uşak Üniversitesi Sosyal Bilimler Enstitüsü, Uşak.

Sezer, A., Çoban, O. \& Akşit, İ. (2017). Öğretmenlerin sorumluluk değeri algılarının incelenmesi. Uşak Üniversitesi Ĕ̌itim Araştırmaları Dergisi, 3(1), 122-144.

Siguardordottir, I. \& Einarsdottir, J. (2016). An action research study in an Icelandic preschool: Develop in consensus about values and values education. International Journal of Early Childhood, 48(2), 161-177.

Symons, D.K. \& Clark, S.E. (2000). A longitudinal study of mother-child relationships anf theory of mind in the preschool period. Social Development, 9(1), 3-23.

Şimşek, N. (2012). Değișen toplumda değerler ve eğitimi: Bireysellik ve dayanışma. Gaziantep University Journal of Social Sciences, 11(4), 1358-1386.

Şirin, N., Şafak, M., Yuvacı, Z., Gür, Ç., Koçak, N. \& Koç, İ. (2016). Değerler eğitimi programının 6 yaş çocuklarına etkisinin incelenmesi ve öğretmen görüşleri. Selçuk Üniversitesi Sosyal Bilimler Dergisi, 35, 261-274.

Temizyürek, F. \& Karagöl, E. (2016). Hedef kitlesi çocuk olan Mehmet Akif Ersoy biyografilerinin değerler eğitimi açısından incelenmesi. Turkish Studies, 11(3), 21752192.

Thornberg, R. (2016). Values education in Nordic preschools: A commentory. International Journal of Early Childhood, 48(2), 241-257.

Topses, G. (2006). Gelişim ve öğrenme psikolojisi. Ankara: Nobel Yayıncılık.

Trawick- Smith, J. (2014). Okul öncesi dönem çocuklarında sosyal ve duygusal gelişim. (Çev. Ed. B. Akman). Ankara: Nobel Yayınevi.

Tut, E. \& Kıroğlu, K. (2017). TRT’nin popüler çocuk şarkıları yarışmasında finale kalan eserlerin değerler eğitimi açısından incelenmesi. Uluslararası Sosyal Araştırmalar Dergisi, 10(48), 561-569.

Utyupova, G.Y., Baisetova, Z.B. \& Mukhamadiyava, A.A. (2016). Value forming education of prospective primary school teachers in Kazakhstan and Germany. International Journal of Environmental \& Science Education, 11(9), 2607-2618. 
Ulavere, P. \& Veisson, M. (2015). Values and values education in Estonian preschool child care. Institutions Journal of Teacher Education for Sustainability, 17(2), 108-124.

Yaka, Ş., Yalçın, D. \& Denizli, E. (2014). Okul öncesi eğitimde verilecek öncelikli değerlere ilişsin veli görüşleri. Değerler Eğitimi Dergisi, 12(28), 169-192.

Yalçın, A., Yemenici, F. Sabancı, H., Kalaycı, K.K., Halisdemir, M., Bakülü, N., Hazar, R.G., Köse, S. \& Ünsal, Y. (2012). Değerler eğitimi etkinlik örnekleri. G. Uyanık-Balat (ed.) İçinde Okul öncesinde değerler ĕgitimi ve etkinlik örnekleri. (ss: 38-130). Ankara: Pegem Akademi.

Yaşaroğlu, C. (2013). Hayat bilgisi dersi kazanımlarının değerler eğitimi açısından incelenmesi. Turkish Studies, 8(7), 849-858.

Yazıc1, A. \& Yazıcı, S. (2015). Saygı ölçeğinin geçerlik ve güvenirlik çalışması. Turkish Studies, 10(14), 769-780. 